\title{
Hubungan antara Defisiensi Besi dengan Attention Deficit/Hyperactivity Disorder pada Anak
}

Desi Fajar Susanti, Sunartini H, Retno Sutomo

Bagian Ilmu Kesehatan Anak Fakultas Kedokteran Universitas Gadjah Mada/RSUP Dr Sardjito, Yogyakarta

Latar belakang. Attention deficit hyperactivity disorder (ADHD) merupakan gangguan perilaku yang paling banyak dijumpai pada anak. Defisiensi besi diduga berperan dalam kejadian ADHD melalui perubahan neurotransmiter dopamin. Feritin serum merupakan indikator reliabel simpanan besi dalam tubuh termasuk otak.

Tujuan. Untuk mengkaji hubungan antara defisiensi besi dan kejadian ADHD pada anak.

Metode. Penelitian cross sectional dilakukan di RSUP Dr Sardjito dan Pusat Pengkajian dan Pengamatan Tumbuh Kembang Anak (P3TKA) Yogyakarta. Diagnosis ADHD berdasarkan kriteria DSM IV-TR. Subjek penelitian dipilih secara consecutive mencakup 35 anak dengan ADHD and 35 anak tanpa ADHD. Dilakukan pengukuran kadar serum feritin pada semua subyek. Hubungan antara defisiensi besi dengan ADHD dianalisis dengan chi square dan rerata feritin serum dengan uji Mean Whitney

Hasil. Kadar feritin serum yang rendah ditemukan pada 34\% anak dengan ADHD dan 25\% pada anak tanpa ADHD tetapi secara statistik tidak berbeda bermakna. Penelitian juga menunjukkan bahwa tidak ada perbedaan rerata feritin serum pada pasien ADHD dan tanpa ADHD $(24.4 \pm 22.04 \mu \mathrm{g} / \mathrm{L}$ vs. $24.4 \pm 19.9 \mu \mathrm{g} / \mathrm{L}$, p > 0,01).

Kesimpulan. Prevalensi defisiensi besi pada anak ADHD dibandingkan tanpa ADHD tidak berbeda secara bermakna.

Sari Pediatri 2015;17(1):29-34.

Kata kunci: attention deficit/hyperactivity disorder, feritin, defisiensi besi

\section{The Relationship between Iron Deficiency and Attention Deficit/ Hyperactivity Disorder in Children}

Desi Fajar Susanti, Sunartini H, Retno Sutomo

Background. Attention deficit hyperactivity disorder (ADHD) is the most common neurobehavioral disorders in children. Iron deficiency has been suggested to contribute in ADHD by altering dopamine neurotransmission. Serum feritin is reliable measurement of iron storage in body tissues including brain.

Objective. To analyze the relationship between iron deficiency and ADHD in children.

Methods. A cross sectional study was conducted at Dr Sardjito hospital and Pusat Pengkajian dan Pengamatan Tumbuh Kembang Anak (P3TKA) Yogyakarta from December 2010 through February 2011. Diagnosis of ADHD was based on DSM IV-TR criteria. Subjects were recruited consecutively, including 35 children with ADHD and 35 normal children. Serum feritin as indicator of iron deficiency was measured in all subject. Association between iron deficiency and ADHD was analyzed by chi square whereas the mean difference of serum feritin level by Mean Whitney Test.

Results. Low serum ferritin levels were found in 34\% of children with ADHD and in 25\% of controls but it reach no different statistically they were not significantly different. Study result showed that there was no significant difference of mean serum feritin level in patients with attention-deficit hyperactivity disorder and controls $((24.4 \pm 22.04 \mu \mathrm{g} / \mathrm{L}$ vs.24.4 $\pm 19.9 \mu \mathrm{g} / \mathrm{L}, \mathrm{p}>0,01)$.

Conclusion. Prevalence of iron deficiency in ADHD group and in control was not statistically different.

Sari Pediatri 2015;17(1):29-34.

Keywords: attention deficit/hyperactivity disorder, ferritin, iron deficiency

\footnotetext{
Alamat korespondensi:

Dr. Desi Fajar Susanti. Bagian Ilmu Kesehatan Anak FK UGM/ SMF Kesehatan Anak/RSUP DR. Sardjito, Jl. Kesehatan No. 1, Yogyakarta 55284 , Telepon+62274561616,+62274587333 ext.543. E-mail:desi_lukman@yahoo.com
} 
$A$ ttention deficit/hyperactivity disorder (ADHD) atau gangguan pemusatan perhatian/hiperaktivitas (GPPH) merupakan suatu gangguan neurobehavioral dan gangguan tumbuh kembang onset anak-anak yang paling sering terjadi. Prevalensi ADHD pada anak secara umum sekitar 4\%12\% (median: 5,8\%) dan 6,68\% di Indonesia. ${ }^{1}$

Penyebab ADHD masih belum diketahui dengan pasti. Faktor genetik diyakini memegang peranan kuat dalam patofisiologi ADHD terutama melibatkan lintasan neurotransmiter dopaminergik. Defisiensi mikronutrien seperti besi diduga turut berperan di dalamnya. Defisiensi besi menyebabkan terjadinya penurunan ekspresi transporter dopamin dan variasi gen transporter dopamin dihubungkan dengan terjadinya ADHD. ${ }^{2}$

Feritin serum merupakan indikator simpanan besi di jaringan tubuh. Menurut Konofal dkk ${ }^{3}$ kadar feritin serum yang rendah ditemukan lebih banyak pada anak dengan ADHD (84\%) dibandingkan anak tanpa ADHD (18\%). Kadar feritin serum yang rendah diketahui memiliki hubungan signifikan dengan keparahan gejala ADHD. ${ }^{3,4}$ Pemberian suplementasi besi pada anak ADHD selama lebih dari 12 minggu menghasilkan adanya penurunan skor $\mathrm{ADHD}$ rating scale. ${ }^{4}$

Peran defisiensi besi dalam patofisiologi timbulnya gejala ADHD sampai saat ini masih kontroversial. Penelitian mengenai kadar besi pada anak ADHD di Indonesia belum banyak dilakukan. Penelitian di Jakarta menyebutkan kadar feritin serum tidak berhubungan dengan keparahan gejala ADHD (menggunakan abbreviated corner teacher rating scale (ACTRS), tetapi penelitian tersebut tidak mengkaji adanya hubungan defisiensi besi dengan kejadian ADHD. 5 Penelitian ini mengkaji hubungan defisiensi besi dengan kejadian ADHD pada anak yang belum pernah dilakukan di Indonesia.

\section{Metode}

Penelitian dengan rancangan cross sectional ini dilakukan pada bulan Desember 2010 sampai dengan Februari 2011. Pengambilan sampel dilakukan dengan cara consecutive sampling. Dengan ditetapkannya $\alpha=0,05$, proporsi defisiensi besi pada anak bukan ADHD $0,18,{ }^{3}$ dan ketepatan prediksi $20 \%$ maka didapatkan subyek penelitian adalah 35 anak usia 3-12 tahun yang terdiagnosis $\mathrm{ADHD}$ sesuai dengan kriteria diagnostik
DSM IV-TR dan 35 anak tanpa ADHD. Subyek yang diketahui terdiagnosis penyakit kronis, seperti tuberkulosis, penyakit ginjal, penyakit jantung, kelainan darah dan keganasan, serta gizi buruk akan dieksklusi dari penelitian ini.

Subjek penelitian menjalani pengambilan darah vena 1 cc 1 kali menggunakan wing needle untuk dilakukan pemeriksaan kadar feritin serum dengan metode atomic absorption spectrophotometry (AAS).

Data dianalisis menggunakan program statistical product and service solution. Untuk mengetahui sebaran data dilakukan uji distribusi normal dengan Kolmogorov Smirnov. Hubungan antara defisiensi besi dengan status ADHD diuji dengan uji chi-square jika memenuhi syarat atau uji Fisher jika tidak memenuhi syarat. Tingkat kemaknaan yang digunakan adalah $\mathrm{p}<0,05$ dengan interval kepercayaan 95\%. Penelitian ini telah mendapatkan persetujuan dari komite Etik Penelitian Kesehatan (KEPK) Fakultas Kedokteran UGM.

\section{Hasil}

Subyek penelitian memiliki distribusi usia 5,1-14,3 tahun dengan median 10,8 tahun. Distribusi usia pada kelompok anak dengan ADHD adalah 5,1-14,3 tahun dengan median 9,6 tahun dan pada kelompok bukan ADHD adalah 10,2-12,0 tahun dengan median 11,1 tahun. Rerata usia terdiagnosis ADHD pada penelitian ini adalah $6,1 \pm 2,5$ tahun. Tumbelaka $\mathrm{dkk}^{5}$ juga menemukan median usia saat pertama kali terdiagnosis ADHD adalah 4 tahun (rentang 2-10 tahun). Karakteristik demografi subyek penelitian tertera pada Tabel 1.

Hasil pemeriksaan kadar serum feritin menunjukkan kadar feritin serum tertinggi pada penelitian ini adalah $102,97 \mu \mathrm{g} / \mathrm{L}$ dan terendah adalah 3,91 $\mu \mathrm{g} / \mathrm{l}$. Rerata kadar feritin serum pada seluruh subjek penelitian adalah $24,45 \mu \mathrm{g} / \mathrm{L} \pm 20,84$. Perbedaan hasil pemeriksaan feritin serum pada kelompok anak ADHD dan bukan ADHD tertera pada Tabel 2 .

\section{Pembahasan}

Pada kelompok ADHD didapatkan jumlah anak lakilaki lebih banyak daripada anak perempuan, dengan perbandingan 6:1. Hasil tersebut sesuai dengan hasil penelitian tentang angka kejadian ADHD yang 
Tabel 1. Karakteristik subyek penelitian

\begin{tabular}{lccc}
\hline Parameter & ADHD & Bukan ADHD & $P^{*}$ \\
\hline Usia & & & \\
$\quad$ Median (rentang) & $9,6(5,1-14,3)$ & $11,1(10,2-12,0)$ & $<0,001$ \\
Jenis kelamin; (n, \%) & & & \\
$\quad$ Laki-laki & $30(66,7)$ & $15(33,3)$ & $<0,001$ \\
$\quad$ Perempuan & $5(20)$ & $20(80)$ & \\
Pendidikan ibu (n, \%) & $19(90,5)$ & $2(9,5)$ & $<0,001$ \\
$\quad$ Tinggi & $16(32,7)$ & $33(67,3)$ & \\
$\quad$ Rendah & $23(92,2)$ & $2(8)$ & $<0,001$ \\
Pendidikan ayah (n, \%) & $12(26,7)$ & $33(73,3)$ & \\
$\quad$ Tinggi & & $19(27,3)$ & \\
$\quad$ Rendah & $29(60,4)$ & $16(72,7)$ & \\
Tingkat sosioekonomi (n, \%) & $6(39,6)$ & & \\
$\quad$ Baik & & & \\
$\quad$ Kurang & 2 & & \\
Psikostimulan & 33 & & \\
$\quad$ Ya & & & \\
$\quad$ Tidak &
\end{tabular}

Keterangan: ${ }^{*} \mathrm{p}<0,05$ bermakna secara statistik

Tabel 2. Hubungan defisiensi besi dengan kejadian ADHD

\begin{tabular}{lccccc}
\hline Defisiensi besi & $\begin{array}{c}\text { ADHD } \\
\mathrm{n}(\%)\end{array}$ & $\begin{array}{c}\text { Bukan ADHD } \\
\mathrm{n}(\%)\end{array}$ & OR & IK95\% & P \\
\hline Status besi & & & & & \\
$\quad$ Defisiensi & $15(57,7)$ & $11(42,3)$ & 1,6 & $0,61-4,35$ & 0,32 \\
$\quad$ Tidak defisiensi & $20(45,5)$ & $24(54,5)$ & & & \\
Rerata feritin serum (SD), $\mu \mathrm{g} / \mathrm{L}$ & $24,43 \pm 22,04$ & $24,48 \pm 19,90$ & & & 0,54 \\
\hline
\end{tabular}

Keterangan: ${ }^{*} \mathrm{p}<0,05$ bermakna secara statistik

mendapatkan rata-rata perbandingan antara laki-laki dan perempuan adalah 4:1.6-8 Anak laki-laki dengan ADHD lebih banyak menderita ADHD tipe hiperaktif dan tipe inattention pada anak perempuan sehingga proporsi anak laki-laki dilaporkan lebih banyak menderita ADHD dibanding anak perempuan. ${ }^{9}$

Feritin serum merupakan indikator besi di dalam tubuh yang reliabel termasuk di otak. Kadarnya yang rendah dapat digunakan sebagai deteksi dini adanya defisiensi besi. Defisiensi besi dapat menyebabkan gangguan neurotransmisi di otak dan diduga memiliki peranan pada patofisiologi ADHD. ${ }^{10}$ Cut-off kadar serum feritin untuk menunjukkan adanya hubungan defisiensi besi dengan ADHD yang digunakan dalam berbagai penelitian adalah bervariasi, mulai dari 12 $\mu \mathrm{g} / \mathrm{L}$ sampai $45 \mu \mathrm{g} / \mathrm{L} .3,10$

Nilai cut off kadar feritin serum yang berbeda tersebut mengambarkan rentang normal pada populasi tetapi tidak menggambarkan kondisi biologi di tubuh sehingga dapat membingungkan dalam evaluasi status besi seseorang. Saat cadangan besi dideplesikan (umumnya digambarkan $<12$ $45 \mu \mathrm{g} / \mathrm{L}$ ) maka akan terjadi penurunan sintesis hemoglobin, gangguan perhatian dan keterlambatan perkembangan psikomotorik. Dalam suatu penelitian yang menggunakan pemeriksaan fungsi sumsum tulang sebagai baku emas, menunjukkan cadangan besi perifer tidak akan terisi penuh sampai tercapainya 
kadar feritin serum $>50-100 \mu \mathrm{g} / \mathrm{L}$. Secara teoritis, simpanan besi di perifer dapat sampai ke sistem saraf pusat dengan menembus sawar darah otak dan hal tersebut dipengaruhi derajat saturasi cadangan besi perifer. Dengan demikian, kadar feritin yang normal untuk sintesis hemoglobin dan mioglobin bisa saja tidak cukup untuk memelihara fungsi neurotransmiter otak. $^{11}$

Penelitian yang dilakukan Cortese $\mathrm{dkk},{ }^{10}$ menggunankan cut-off kadar serum feritin $<45$ $\mu \mathrm{g} / \mathrm{L}$ dalam penelitiannya, menemukan $60 \%$ anak ADHD mengalami defisiensi besi. Konofal dkk, ${ }^{3}$ menggunakan cut-off kadar serum feritin $<30$ $\mu \mathrm{g} / \mathrm{L}$ dalam penelitiannya, menemukan $84 \%$ anak ADHD mengalami defisiensi besi dan $18 \%$ pada kelompok anak bukan ADHD $(\mathrm{p}<0,001)$. Sementara itu, Lahat dkk, ${ }^{12}$ menggunakan cut off kadar feritin serum $20 \mu \mathrm{g} / \mathrm{L}$ dalam penelitiannya, menemukan $56 \%$ anak ADHD mengalami defisiensi besi. Sebaliknya, Tumbelaka $\mathrm{dkk}^{5}$ dan Millichap $\mathrm{dkk}^{13}$ dengan menggunakan nilai cut off yang sama hanya menemukan prevalensi defisiensi besi pada anak ADHD masing-masing 15\% dan 18\%.

Penelitian ini menggunakan cut-off $<15 \mu \mathrm{g} / \mathrm{L}$ sesuai dengan definisi dari International nutritional anemia consultative group (INACG) dan sudah direvisi WHO di tahun 1993. Kadar serum feritin dibagi berdasar kan usia dalam menggambarkan simpanan besi dalam tubuh. Untuk usia $<5$ tahun, kadar feritin serum $<2$ $\mu \mathrm{g} / \mathrm{L}$ menggambarkan adanya deplesi simpanan besi, sedangkan usia $>5$ tahun, kadar feritin serum $<15 \mu \mathrm{g} / \mathrm{L}$ menggambarkan deplesi simpanan besi. Nilai cut off penelitian ini tidak jauh berbeda dengan penelitian yang dilakukan di India, yaitu $<12 \mu \mathrm{g} / \mathrm{L}$. Hasil penelitian tersebut menemukan 92\% kelompok anak ADHD mengalami defisiensi besi, sementara tidak satu pun ditemukan pada kelompok bukan ADHD. ${ }^{14}$

Penelitian ini menemukan proporsi kejadian defisiensi besi lebih tinggi pada kelompok anak dengan $\mathrm{ADHD}(57,7 \%)$ dibandingkan anak tanpa ADHD (42,3\%), tetapi secara statistik tidak berbeda bermakna. Hal tersebut kemungkinan dapat terjadi karena prevalensi defisiensi besi pada anak di Indonesia masih tinggi. Menurut hasil survei kesehatan rumah tangga (SKRT) tahun 2001, prevalensi defisiensi besi pada anak usia sekolah dan remaja $26,5 \%$. Penelitian lain menyebutkan $47,2 \%$ anak usia sekolah mengalami defisiensi besi. Prevalensi defisiensi besi yang tinggi pada anak usia sekolah tersebut dapat menyebabkan proporsi anak yang mengalami defisiensi besi pada kelompok anak bukan ADHD tidak berbeda jauh dengan kelompok anak ADHD.

Penelitian ini menunjukkan tidak ada perbedaan kadar serum feritin pada kelompok anak ADHD dibandingkan kelompok anak sehat. Hal tersebut sesuai dengan penelitian Danfrancesco dkk ${ }^{15}$ yang menemukan kadar serum feritin pada anak ADHD tidak berbeda bermakna dibanding kelompok bukan ADHD. Hal yang sama juga ditemukan Millichap $\mathrm{dkk}^{13}$ pada penelitiannya. Sebaliknya, Juneja $\mathrm{dkk}^{14}$ menyebutkan bahwa rerata kadar serum feritin pada anak ADHD lebih rendah dibanding kontrol. Konofal $\mathrm{dkk}^{3}$ juga menemukan adanya perbedaan kadar feritin pada anak ADHD dengan kontrol.

Perbedaan mengenai rerata kadar feritin pada penelitian di atas dapat disebabkan oleh berbagai hal. Penggunaan psikostimulan pada subjek penelitian diduga dapat memengaruhi hasil penelitian tentang defisiensi besi pada anak ADHD. Seperti yang kita ketahui bahwa salah satu efek samping terapi stimulan adalah penurunan nafsu makan. ${ }^{15}$ Penurunan nafsu makan dapat menyebabkan penurunan asupan makanan yang salah satunya mengandung zat besi sehingga akan menyebabkan kadar serum feritin ikut turun. Dengan demikian, menilai status besi pada pasien ADHD yang belum pernah mendapat terapi psikostimulan dapat menghindari terjadinya bias. ${ }^{15}$ Pada penelitian ini, hanya dua anak ADHD yang menggunakan terapi psiko stimulan sehingga tidak dapat dilakukan analisis secara statistik.

Beberapa penelitian menjelaskan jenis dan lama pemakaian terapi psikostimulan yang digunakan kelompok anak ADHD, tetapi tidak ada pembahasan secara statistik apakah lama pemakaian terapi psiko stimulan memengaruhi terjadinya defisiensi besi pada anak ADHD. Juneja $\mathrm{dkk},{ }^{14}$ dalam penelitiannya, menemukan perbedaan rerata kadar feritin serum antara kelompok anak ADHD dan bukan ADHD tidak menyebutkan berapa lama penggunaan terapi psikostimulan setelah diagnosis ditegakkan (3 tahun sebelum penelitian dimulai). Kelompok anak ADHD pada penelitian Konofal $\mathrm{dkk}^{3}$ sudah bebas psikostimulan selama 2 bulan setelah pemakaian 1-2 tahun saat dilakukan pemeriksaan kadar feritin serum. Namun, tidak jelas apakah periode tersebut cukup untuk menormalkan defisiensi nutrisi akibat terapi psikostimulan sebelumnya.

Sementara itu, Donfrancesco dkk ${ }^{15}$ menyebutkan 
bahwa pada penelitiannya, kelompok anak ADHD baru mendapatkan terapi psikostimulan 3 bulan sehingga kadar feritin serum tidak berbeda dibanding kananak tanpa ADHD. Hal tersebut di atas menunjukkan penggunaan terapi psikostimulan dalam jangka waktu lama dapat memengaruhi kadar serum feritin pada anak ADHD menjadi rendah dibandingkan anak bukan ADHD meskipun tidak ada data empiris berapa lama pemkaian psikostimulan dapat memberi efek pada kadar feritin

Perbedaan hasil penelitian ini dengan penelitian di atas, selain disebabkan oleh cut- off, kadar feritin, dan perbedaan metode pengukuran serum feritin yang digunakan juga kemungkinan dikarenakan status besi tergantung pada usia, jenis kelamin, ras, dan faktor sosial ekonomi seseorang. Pada penelitian ini, proporsi tingkat sosial ekonomi tinggi, pendidikan ayah dan ibu tinggi diketahui lebih banyak pada kelompok anak ADHD. Namun, setelah dilakukan analisis bivariat menunjukkan hanya tingkat sosioekonomi yang memiliki hubungan dengan defisiensi besi,

Pendapatan per kapita keluarga berpengaruh terhadap pemenuhan kebutuhan gizi dalam hal ini mikronutrien besi. Berdasarkan hal tersebut, pemenuhan kebutuhan zat besi pada kelompok anak ADHD sangat mungkin lebih baik dibanding anak tanpa ADHD sehingga berdampak pada kadar feritin serum. ${ }^{2}$

Penelitian ini tidak dapat mengambil kesimpulan bahwa defisiensi besi tidak terlibat pada patofisiologi ADHD. Seperti kita ketahui bahwa serum feritin merupakan salah satu penanda status besi di perifer dan penurunan sejumlah besi di perifer dapat memberi dampak pada kadar besi di pusat. Namun demikian, sejauh mana serum feritin memengaruhi kadar besi di otak tetap belum jelas. ${ }^{10}$

Kelemahan penelitian ini adalah pengambilan kelompok anak tanpa ADHD sebagai kelompok pembanding bukan dari populasi yang sama dengan kelompok anak dengan ADHD dikarenakan sulit mencari anak sehat di RS dr Sardjito dan Pusat Pengkajian dan Pengamatan Tumbuh Kembang Anak (bias seleksi). Di samping itu, karena keterbatasan waktu dan biaya, pemeriksaan kadar serum feritin hanya dilakukan sekali serta tidak dilakukan pemeriksaan penunjang lain untuk menyingkirkan adanya anemia dan inflamasi. Seperti kita ketahui, feritin merupakan indikator paling baik dan mudah untuk menilai cadangan besi serta memiliki spesifitas tinggi untuk defisiensi besi, tetapi feritin juga merupakan protein fase akut yang kadarnya meningkat pada kondisi inflamasi. Hal tersebut dapat memengaruhi kadar serum feritin subyek penelitian..

\section{Kesimpulan}

Prevalensi defisiensi besi lebih banyak pada kelompok anak ADHD dibandingkan kelompok anak sehat, tetapi perbedaan tersebut tidak bermakna. Rerata kadar serum feritin anak dengan ADHD tidak berbeda dengan anak tanpa ADHD. Defisiensi besi tidak berhubungan dengan kejadian ADHD pada anak.

\section{Daftar pustaka}

1. Andres MA. Prevalence, comorbidity, risk factors and service utilisation of disruptive behaviour disorders in community sample of children in Valencia (Spain). Soc Psy Epid 1999;34:175-9.

2. Biederman J. Attention- deficit/hyperactivity disorder: a selective overview. Biol Psychiatry 2005;57:1215-20.

3. Konofal E, Lecendreux M, Arnulf I, Mouren MC. Iron deficiency in children with attention deficit hyperactivity disorder. Arch Pediatr Adolesc Med 2004;158:1113-5

4. Oner O, Alkar OP, Oner P. Relation of ferritin levels with symptom ratings and cognitive performance in children with attention deficit-hyperactivity disorder. Pediatr Int 2008;50:40-4

5. Tumbelaka IAP, Pusponegoro HD, Rohsiswatmo R. Correlation between serum feritin levels and attentiondeficit/hyperactivity disorder symptom scores in children based on the abbreviated conners teachers rating scale. Paediatr Indones 2012;52:329-35.

6. American Academy of Pediatrics, Committee on Quality Improvement, Subcommittee on Attention-Deficit/ Hyperactivity Disorder. Clinical practice guideline: Diagnosis and evaluation of the child with attention- deficit/ hyperactivity disorder. Pediatrics 2001;108:1033-44.

7. Damodoro N. Sekilas studi epidemiologi disfungsional minimal otak. Dalam: Ibrahim N. Buku tahunan I neurologi simposium minimal brain damage pertemuan regional VI IDASI Jateng-DIY. Tawangmangu; 1989.

8. Kiswarjanu. Prevalensi dan faktor resiko gangguan pemusatan perhatian pada murid taman kanak-kanak di kotamadya Yogyakarta, (Tesis:). Fakultas Kedokteran UGM, Yogyakarta;1998.

9. Rowland AS, Lesesne CA, Abramowitz AJ. The 
epidemiology of attention deficit hyperactivity disorder (ADHD): a public health view. MRDD Res Rev 2002;8:162-70.

10. Cortese S, Konofal E, Bernardina BD, Mouren MC, Lecendreux, M. Sleep disturbances and serum feritin levels in children with attention-deficit/hyperactivity disorder. Eur Child Adolesc Psychiatry2009;18:393-9.

11. Piccietti D. Is iron deficiency an underlying cause of pediatric restless legs syndrome and of attention-deficit/ hyperactivity disorder?. Sleep Med 2007;8:693-4.

12. Lahat E, Heyman E, Livne A, Goldman M, Berkovitch $\mathrm{M}$, Zachor D. Iron deficiency in children with attention deficit hyperactivity disorder. IMAJ 2011;13:530-3.

13. Milichap JG, Yoe MM. Davidson SL. Serum feritin in children with attention deficit hyperactivity disorder. Pediatr Neurol 2006;34:200-3

14. Juneja M, Jain R, Singh V, Mallika D. Iron deficiency in Indian children with attention deficit hyperactivity disorder. Indian Pediatrics 2010;1-4

15. Donfrancesco R, Parisi P, Vanacore N, Martines F, Sargentini V, Cortese S. Iron and ADHD: time to move beyond serum feritin levels. J. Attention Dis 2013;17:347-57. 